\title{
Foto i kommunikasjon med demente - «Jeg tror det ikke før jeg ser det!»
}

\section{Eva Dolva}

Spesialsykepleier i psykiatri

\section{Marit Nåvik}

Ergoterapaut

Eldre

\section{Demens Psykisk lidelse}

Sykepleien 2003;91(19):40-44

DOI: 10.4220/sykepleiens.2003.0059

SAMMENDRAG: Artikkelen beskriver et tverrfaglig pilotprosjekt, hvor foto ble brukt i kommunikasjon med personer med demens. Ved Utredningsenheten, Seksjon for Alderspsykiatri ved Sykehuset Telemark HF gis et behandlingstilbud til personer med alvorlig grad av demens og tilleggsproblematikk som for eksempel angst, depresjon, hallusinasjoner, vrangforestillinger eller problemadferd.

Personalets utfordring er å få pasienten til å forstå, huske, gjenkjenne når han ikke vet hva som skal skje, hvor, hvorfor og med hvem. Prosjektet ønsket å unders $\varnothing$ ke om foto, kombinert med verbal instruksjon og kroppsspråk, kunne være et behandlingstiltak for å få pasienten til å huske, forstå og handle. Likedan om bruk av foto bidro til å forebygge uro, og om foto som behandlingstiltak kunne innpasses i postens eksisterende behandlingstiltak. Konklusjonen er at foto gir muligheter i kommunikasjon med mennesker med demens.

Utredningsenheten, gjennomførte høsten 2001 et tverrfaglig pilotprosjekt, hvor foto ble brukt i kommunikasjon med personer med demens. 
Seksjon for Alderspsykiatri er en seksjon under Psykiatrisk Sjukehusklinikk, og har sentralsjukehusfunksjon for Telemark fylke innen fagområdet alderspsykiatri.

Seksjonen skal utrede og behandle pasienter med debut av psykiske lidelser etter 65 år og aldersdemente hvor diagnosen er vanskelig å stille, eller det er betydelig psykiatrisk og/eller adferdsmessig tilleggsproblematikk. Seksjonen består av en sengepost med 15 sengeplasser og en egen alderspsykiatrisk poliklinikk.

Utredningsenheten gir et behandlingstilbud til personer med demens med tilleggsproblematikk. Tilleggsproblematikk vil si psykiatriske symptomer i form av for eksempel angst, depresjon, hallusinasjoner, vrangforestillinger eller problemadferd. Det kan også være en tilstand med konfusjon i tillegg til demens. Tilbudet skal være utredning både i forhold til diagnose og igangsetting av behandling (medikamentell, miljøbehandling, veiledning).

Det vil si at vi til enhver tid i utredningsenheten har personer med alvorlig grad av demens, og som alle har en form for tilleggsproblematikk. Det er stor variasjon i forhold til hva pasienten trenger hjelp til i daglige gjøremål og i pasientens psykiske og mentale tilstand, og de fleste trenger hjelp til personlig hygiene i større og mindre grad.

Personalets utfordring er å få pasienten til å forstå/huske/gjenkjenne når han ikke vet hva som skal skje, hvor, hvorfor og med hvem. Uro og misforståelser oppstår ofte når personalet $\varnothing$ nsker at pasienten skal over i en ny aktivitet, forflytte seg fra ett sted til ett annet, endre arena., men at pasienten enten ikke er enig eller ikke forstår det vi prøver å formidle. Vil du bli med? - Nå skal vi.... - Skal du ....? - Vil du.....?

Pasienten trenger hjelp fra personalet til å holde tråden i tilværelsen, finne ro og praktisk hjelp til daglige giøremål. Vi har også en utfordring når pasienten vil hjem.

Utfordring for personalet er å hjelpe den enkelte å hente fram tidligere kompetanse, erfaringer, rutiner og ferdigheter. Hvilke stimuli, innspill, nøkler, holdepunkt kan vi gi som gjør en person med demens i stand til å huske, forstå og handle.

Prosjektet tok ikke hensyn til hva slags type demensdiagnose pasienten hadde, men tok utgangspunkt i symptomer og problemer i hverdagen i forhold til hukommelse, kommunikasjon, forståelse og samhandling med hjelpere. 
Vi ønsket å ta utgangspunkt i evne til gjenkjenning framfor gjenkalling (1). Ved gjenkalling husker en spontant uten hjelp fra omgivelsene, en husker fritt (2). Ved gjenkjenning husker en ved hjelp av detaljer eller ledetråder, som gjør at en assosierer og dermed husker mer. Disse ledetrådene kan være av visuell, auditiv, eller kinestetisk art, eller en kombinasjon. Ord som har høy assosiasjonsmulighet, gir større mulighet for både å huske mer og å bruke språket (3).

Ansatte i utredningsenheten har lang erfaring i å benytte et bredt spekter av tilnærming i samhandling med pasientene:

- Realitetsorientering kan ha både et visuelt og verbalt uttrykk $(4,5)$. Gjenkjennelige omgivelser vil være realitetsorienterende. Vi bruker mye verbal realitetsorientering som naturlig kan flettes inn i samtalen om tid, sted, situasjon og person uten å avdekke svikten, eller det brukes som respons på pasientens utsagn.

- Avledning kan være samtale om andre tema eller praktiske gjøremål, eller en hyggelig aktivitet som kan virke samlende og som gjør at pasienten kan hente seg inn. Det kan også være en enetale fra vår side om et tema en vet pasienten har kjennskap til eller interesse av, for å fange oppmerksomhet som i sin tur kan føre til at en făr i gang en dialog.

- Validering vil si at en legger logisk tenkning bak seg, en glemmer fakta, men godtar pasientens opplevelse av virkeligheten og hans følelser forbundet med det (6). En bruker reflekterende tilbakemelding, en griper verbalt fatt $i$ pasientens utsagn, gjentar nøkkelord i det han sier, en anerkjenner pasientens budskap. En prøver å svare på pasientens kroppsspråk ved å speile hans, for eksempel ved å sitte hvis han sitter, samt at en bruker berøring hvor det virker st $\varnothing t t e n d e ~ o g$ beroligende på pasienten. I validering ligger det at en unngår argumentering og korrigering, og at en snakker med lav, varm, vennlig stemme.

- Containing ligner mye på validering, men en møter pasienten enda mer defensivt (4). En tar imot pasientens budskap uten å korrigere, en er kravløs i egne utsagn, og stiller helst ikke spørsmål som krever noe av pasienten. En møter på følelser ved å lytte, en forholder seg taus, og er deltagende i kroppsholdning og utsagn, nikker, tar på armen, bruker ufarlige ikkeprovoserende utsagn som dette høres ikke greit ut - jeg skjønner - hmm.

I tillegg til den verbale tilnærming, jobbes det bevisst med tilrettelegging av det fysiske miljøet rundt pasienten; begrense stimuli, støy og bevegelser til et minimum for å dempe uro og forvirring. 


\section{Problemstillinger}

Vi ønsket å unders $\varnothing$ ke

- i hvilke sammenhenger foto kombinert med verbal instruksjon og kroppsspråk, kan være et behandlingstiltak vi kan bruke for at personer med demens bedre kan forstå veiledning i forhold til daglige aktiviteter, som for eksempel personlig hygiene og måltider.

- om bruk av foto kan bidra til å forebygge uro og hjelpe pasienten å ha oversikt over hva som skal skje, for eksempel flytting, hjemreise

- hvordan foto som behandlingstiltak kan innpasses i postens eksisterende behandlingsopplegg.

Vi var kjent med at foto var brukt for barn med funksjonshemninger (7) og i forbindelse med minnearbeid ved demens $(8,9,10,11,12,13)$, men vi $\varnothing$ nsket i prosjektet å ha fokus på direkte kommunikasjon i hverdagen. Prosjektlederne fikk veiledning fra nasjonalt kompetansesenter for aldersdemens.

\section{Etiske og juridiske aspekter}

Innledningsvis var det nødvendig med en avklaring om etiske og juridiske spørsmål ved å ta bilder av innlagte pasienter uten samtykkekompetanse. Seksjonsledelsen tok kontakt med klinikkledelsen, Kontrollkommisjonen og fylkeslegen, som henviste til Regional komité for medisinsk forskningsetikk. Vi sendte søknad dit med beskrivelse av prosjektet og etiske betraktninger rundt problemstillingen.

\section{Informasjon og samtykke}

Pårørende fikk en skriftlig informasjon hvor vi ba om samtykke til deltagelse i prosjektet. Vi laget en forenklet skriftlig informasjon til pasienten fordi hans mulighet til å gi samtykke og til å velge om han/hun ville delta, er redusert. Samtykke stiller krav til kognitiv fungering, evne til å oppfatte, forstå og vurdere konsekvenser.

\section{Fotografering av tvangsinnlagte pasienter}

Fotografering av pasienter som er innlagt mot sin vilje, stilte krav til at tiltaket skulle gjennomføres etter faglige vurderinger av pasientens behov. Tiltaket skulle introduseres som en av flere tilnærmingsmåter, og ville være et supplement til eksisterende tilbud. Pasienten skulle ikke miste andre tilbud ved deltagelse i prosjektet. 


\section{Bruk og oppbevaring av fotografiene}

Det ble utarbeidet prosedyrer for oppbevaring, terapeutisk bruk av bildene, lagring og makulering. Det var viktig å sikre at bildene ble oppbevart forsvarlig, på samme måte som øvrig dokumentasjon ved seksjonen.

Pasientens behov, ressurser og begrensninger skulle være utgangspunkt for iverksettelse av tiltaket. Pasientens respons skulle vurderes; om vi oppnådde $\varnothing$ nsket resultat, eller om tiltaket var uhensiktsmessig.

\section{Inklusjonskriterier}

Det ble satt opp følgende inklusjonskriterier for utvelgelse av deltagere i prosjektet:

Pasienten skulle

- være søkt til Utredningsenheten

- ha demens/hukommelsesproblemer

- ha problemer i forhold til ADL (activities of daily living/dagliglivets gjøremål) og samhandling/samarbeid

- ha kommunikasjonsproblemer

- ha tilstrekkelig synsfunksjon

- ikke ha alvorlig grad av agnosi

Prosjektlederne foretok hjemmebes $\varnothing \mathrm{k}$ hos pasienter som var aktuelle for innleggelse i prosjektperioden. For å vurdere pasientens hukommelse, kommunikasjon og praktisk fungering ønsket vi en samtale med pårørende, eventuelt hjelpeapparatet, samt en samtale med enkel vurdering av pasienten. Vi $\emptyset$ nsket etter en kartlegging å vurdere om foto kunne være et aktuelt tiltak for pasienten ved innleggelse i Seksjon for alderspsykiatri, Utredningsposten.

\section{Integrering i postens behandlingstilbud}

Et viktig element i prosjektplanleggingen var at foto skulle inngå på samme måte som andre tiltak i forhold til pasientene på utredningsenheten. Eksisterende møtestruktur, planlegging, dokumentasjon og evaluering av tiltak skulle benyttes. Registrering av effekt av bildene skulle gjøres fortløpende både i pleieplan og på egne registreringsark. Videreføring av tiltaket skulle drøftes ved utskrivning av pasientene. Hvis tiltaket var effektivt, skulle bildene kunne følge med pasienten og brukes av dem som skulle samhandle og samarbeide med pasienten videre. 


\section{Hvilke bilder og situasjoner}

Vi valgte i dette pilotprosjektet å se på situasjoner hvor vi som miljøpersonale ofte opplever at sviktende kommunikasjon fører til frustrasjon og misforståelser.

Vi ønsket å bruke bilder

- ved introduksjon til daglige gjøremål som for eksempel tannpuss, hårstell og måltider

- for at pasienten skulle få en oversikt over hva som skal skje eller nylig har skjedd, for eksempel bes $\varnothing \mathrm{k}$ av pårørende, flytting til ny bolig

- i forhold til trivsel, for eksempel bilder av pasienten som løser kryssord, eller har besøk av pårørende

Vi skulle ta bilder av pasienten i avdelingen i ulike hverdagsaktiviteter, alene, sammen med pårørende eller personalet. Det skulle ikke tas bilder som var blamerende for pasienten. Bildene ble laget i A4 størrelse.

Vi valgte underveis i prosjektet å gradere bildene for å se hvilke bilder som hadde størst effekt. Vi tok bilder med ulik mengde informasjon; enkle bilder med så få gjenstander som mulig, bilder som skulle beskrive en situasjon eller et sted og bilder hvor pasienten selv var deltagende i en aktivitet.

De enkleste bildene av ting, aktiviteter eller steder var generelle bilder som kunne brukes av flere pasienter. Bilder av pasienten i aktivitet skulle lages til den enkelte. Ved å prøve ut ulike bilder med ulik mengde informasjon ønsket vi å se hvor detaljerte bildene måtte være for å gi ønsket effekt.

Vi graderte bildene på følgende måte:

- Pasienten i aktivitet (pasient som sitter ved frokostbord og spiser).

- Bilde av situasjonen (dekket frokostbord).

- Objekter knyttet til aktiviteten (melkeglass og påsmurt brødskive).

Hvilke bilder, og når de skulle brukes, ble planlagt individuelt. For noen kunne ett bilde introdusere aktiviteten. For andre kunne det være aktuelt med nytt bilde i forhold til hver enkelt delhandling, hvert ledd av aktiviteten.

\section{Effekt av tiltak}


For å vurdere om bruk av bilder som behandlingstiltak hadde effekt, valgte vi å gjøre en direkte observasjon av hver pasient. Vi utarbeidet en guide for å registrere personalets og pasientens tale, gester, plassering, mimikk og følelsesmessig tilstand. Guiden ble laget med utgangspunkt i beskrivelser av samhandling og nonverbal kommunikasjon $(14,15,16)$.

For å teste reliabiliteten av den direkte observasjonen gjorde vi en videoobservasjon. Vi gjorde registreringer hver gang foto ble benyttet. Vi ønsket tilbakemeldinger på hva en ønsket å oppnå ved bruk av bilder, hva en gjorde i tillegg til foto og personalets vurderinger av effekt. Det ble gjennomført et opplæringsprogram for personalet i bruk av foto, kamera og registreringsskjema.

For å gjennomføre prosjektet trengte vi digitalt kamera, bærbar PC, projektor, fotoprogram, fotoprinter, CD-brenner og skanner. I tillegg var det nødvendig å tilegne seg kunnskap om bruk av det tekniske utstyret og bildeprogram.

\section{Resultater}

Foto ble brukt i forhold til to pasienter i prosjektperioden. Personalet fylte ut 46 registreringsskjema vedrørende bruk og effekt av foto.

Hensikten med bruk av bilder var ulike for de to pasientene. Etter innledende kartlegging så det ut som problematikk og funksjon var nokså lik, men etter direkte observasjon i sengepost så vi at hensikten med bruk av foto måtte bli forskjellig.

Oversikten beskriver hva vi ønsket å oppnå, hvor mange ganger bilder ble brukt og om vi oppnådde det vi ønsket.

\section{Pasient 1}

- Hjelpe pasienten til å forstå hva som skal skje, hvilken aktivitet som skal introduseres

- Frokost

- Hvile

- ADL

- Trivsel

\section{Pasient 2}

- Forberedelse, motivasjon til flytting til sykehjem

- Trivsel 


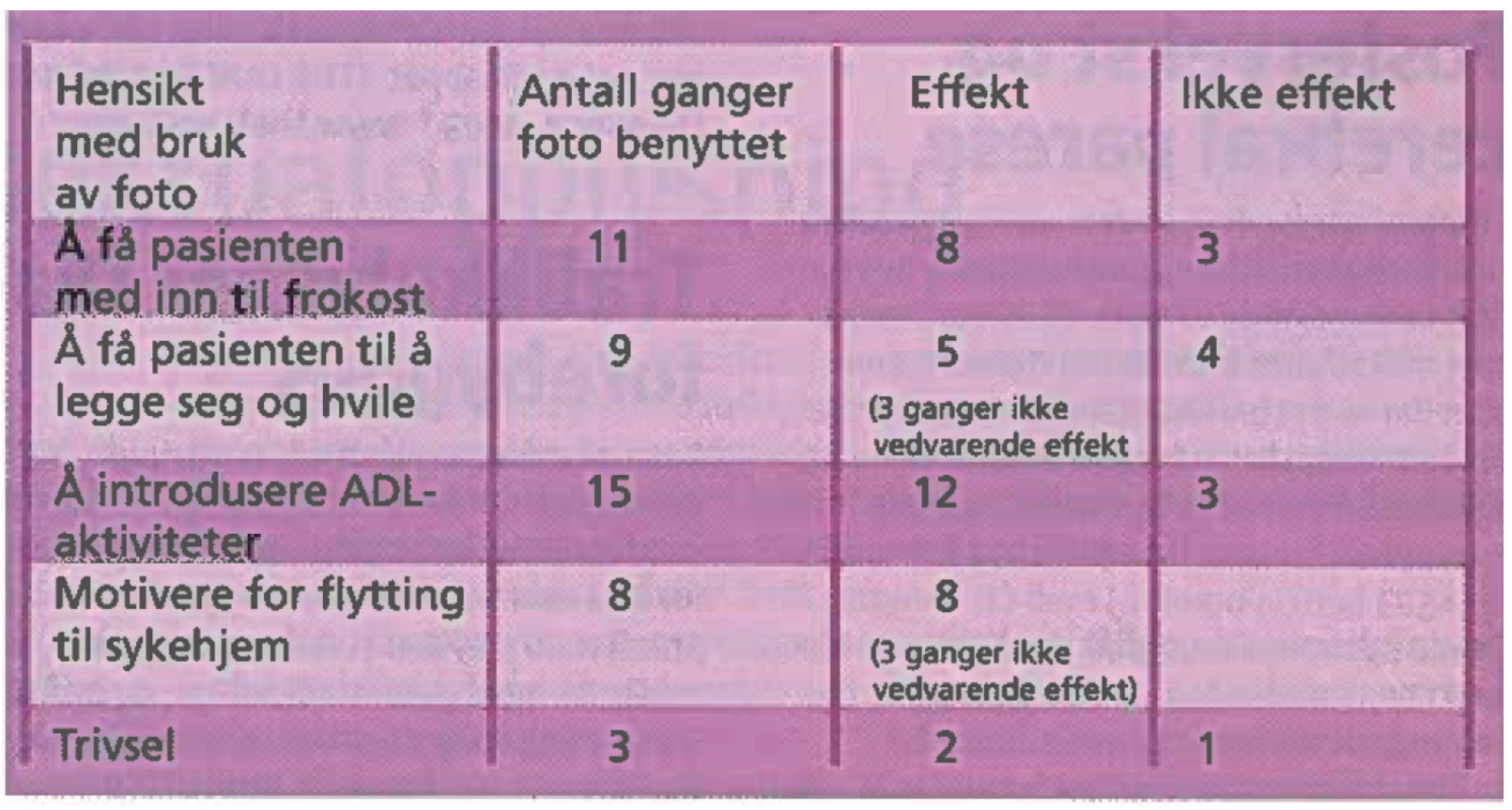

Personalets registreringer viste at bruk av bilder hadde effekt 35 av 46 ganger. Seks registreringer viste av bildene hadde effekt, men ikke vedvarende: Pasienten la seg ned for å hvile etter å ha blitt vist bilde, men reiste seg etter kort tid opp igjen. 11 registreringer viste at bildene ikke hadde effekt.

For pasient 2 ble det vist en serie med bilder av nytt bosted og han selv på det nye bostedet. For pasient 1 benyttet vi graderte bilder i forhold til ADL, hvile og trivsel.

Tilbakemeldinger om pasient 1 , gjør at vi vurderte foto som hensiktsmessig tilnærming i forhold til introduksjon til ADL-aktiviteter og som trivselsfaktor.

For pasient $\mathbf{2}$ har vi et generelt inntrykk og tilbakemeldinger fra personalet, som gjør at vi vurderer foto som hensiktsmessig i kommunikasjon i forhold til å motivere for flytting.

\section{Evaluering}

Siden dette er et pilotprosjekt med bare to pasienter, er det vanskelig å trekke konklusjoner om effekt av foto som tiltak. I samhandling med mennesker med demens må vi som personale hele tiden spille på et bredt repertoar av kommunikasjons- og tilnærmingsmåter. Det kan være vanskelig å slå fast hvilken faktor som gir resultat. Dagsform, tilgjengelighet og grad av forvirring hos den vi skal hjelpe, er variabler som påvirker utfallet av enhver samhandling.

Tilbakemeldinger fra personalet, utfylte registreringsskjemaer og muntlige rapporter gjør at vi ser bruk av foto som en mulig innfallsvinkel for enkelte pasienter til bedre å forstå veiledning, forebygge uro og gi oversikt og forutsigbarhet. 
Konklusjonen er at foto gir muligheter i kommunikasjon med mennesker med demens. Vi ønsker å prøve ut foto som kommunikasjonsmiddel på et større antall pasienter, samtidig som det arbeides med å integrere tiltaket i avdelingens daglige drift.

\section{Litteratur}

1. Engedal K, Haugen PK. Aldersdemens, fakta og utfordringer. Sem: INFO-banken, 1999.

2. Engedal K, Haugen PK. Aldersdemens, fakta og utfordringer. Sem: INFO-banken, 1996.

3. Alstad K. Hvorfor svikter kommunikasjonsevnen? Demens 2001; 5 (2).

4. Strand L. Fra kaos mot samling, mestring og helhet. Psykiatrisk sykepleie til psykiatriske pasienter. Oslo: Gyldendal Norsk Forlag, 1990.

4. Horn BL, Stendahl LH. Å forstå når man ikke forstår. Sem: INFO-banken, 1993.

5. Feil N. Validation: Feilmetoden: Hur man hjelper dersorienterade eldre- eldre. Lund: Studentlitteratur, 1994.

6. Tetzschner S, Martinsen H. Språk og funksjonshemning. Oslo: Gyldendal Norsk Forlag, 1991

8. Aremyr G. (1995.) Leve livet glemsk. Oslo: Kommuneforlaget,

9. Olsen TG, Gundersen K, Moynahan L, Solberg S. Min historie. Neerbø: Haugtussa forlag, 1994.

10. Olaviken behandlingssenter. Informasjon om fotoalbum. Bergen: Olaviken behandlingssenter - ukjent årstall

11. Killinck J. Reminiscence by recreation, Journal of Dementia Care, 1999; nov/des: 2425 .

12. Weiner RL, Abramowitz L. Use of Photographs as Therapy for Demented Elderly. Activities, Adaptation \& Aging, 1997; Vol 21: 47-51.

13. Løwendahl B. Det levede liv. Frederikshavn DK: Dalfolo Forlag, 1996.

14. Ellingham B, Ness NE. Modell for Menneskelig Aktivitet. Ergoterapeuten, 1997; 13: 4655 .

15. Øyslebø O. Det usagte sagte- Studier i ikkeverbal kommunikasjon i tale og tekst. Oslo: Universitetsforlaget, 1992.

16. Horne H, Øyen B. Målrettet miljøarbeid del 1-3. G.R.D.forlag, 1991. 